\title{
BIOEDUSCIENCE
}

ISSN: 2614-1558

http://journal.uhamka.ac.id/index.php/bioeduscience

\section{The Implementation of Flipped Learning Model in Squash Method Material in Microtechnique Courses}

\author{
Puspita Ratna Susilawati \\ 1Pendidikan Biologi, FKIP, Universitas Sanata Dharma, Maguwoharjo, Depok, Sleman, Indonesia 55282 \\ *Corespondent email: ratna.puspita@gmail.com
}

\section{ARTICLE INFO}

Article history:

Received: 27 Maret 2020

Accepted: 06 Sept 2020

Published: 31 Des 2020

\section{Keywords:}

Flipped learning

Microtechnique

Squash method

Understanding

\section{Kata kunci:}

Flipped learning

Metode Squash

Mikroteknik

Pemahaman

\section{A B S T R A C T}

Background: The implementation of flipped learning could be one of the solutions offered so that practicum that was limit by time could be carried out. This study aimed to determine the effect of implementing the flipped learning model on student understanding of the squash method material in microtechnique courses. Methods: This study was a quasi-experimental study with a nonequivalent control group design. In the treatment group, the flipped learning model was applied then an analysis of its effect on student understanding was carried out. The research data obtained through the pretest and post-test. The pretest evaluated the ability to remember and understand, while the post-test evaluates the ability to analyse, evaluate, and create. The $\mathrm{N}$-gain values were calculated from the pretest and post-test. The N-gain values of the treatment and control classes were tested for normality and homogeneity then the Mann-Whitney $U$ test was performed to determine the difference between the two. Results: The increase in the mean value in the treatment class was higher than in the control class. The treatment class was 5.2, while the control class was 0.82 . The percentage of students who showed a high and moderate $\mathrm{N}$-gain score in the treatment class was $54.05 \%$, while the control class was $40 \%$. There was no difference between the $\mathrm{N}$-gain value in the treatment and control classes. The flipped learning model's implementation did not affect student understanding but had been able to increase student understanding of the squash method material. Conclusions: The flipped learning model could be applied as a solution to practical problems constrained by time constraints.

\section{Penerapan Flipped Learning pada Materi Metode Squash pada Mata Kuliah Mikroteknik}

\section{A B S T R A K}

Backgrond: Penerapan flipped learning dapat menjadi salah satu solusi yang ditawarkan agar praktikum yang terkendala keterbatasan waktu dapat tetap dilaksanakan. Penelitian ini bertujuan untuk mengetahui pengaruh penerapan model flipped learning terhadap pemahaman mahasiswa pada materi metode squash pada mata kuliah mikroteknik. Metode: Penelitian ini merupakan penelitian eksperimen kuasi dengan non-equivalent control group design. Pada kelompok perlakuan diterapkan model flipped learning dan dilakukan analisis pengaruhnya terhadap pemahaman mahasiswa. Data penelitian diperoleh melalui pretest dan posttest. Pretest digunakan untuk mengevaluasi kemampuan remembering dan understanding sedangkan posttest mengevaluasi kemampuan analysis, evaluating dan creating. Data nilai pretest dan posttest digunakan untuk menghitung nilai N-gain. Nilai N-gain kelas perlakuan dan kontrol diuji normalitas dan homogenitasnya kemudian dilakukan uji Mann-Whitney U untuk mengetahui perbedaan diantara keduanya. Hasil: Peningkatan rerata nilai pada kelas perlakuan lebih tinggi daripada kelas kontrol yaitu pada kelas perlakuan sebesar 5,2 sedangkan pada kelas kontrol sebesar 0,82. Persentase mahasiswa yang menunjukkan nilai $\mathrm{N}$-gain kategori tinggi dan sedang pada kelas perlakuan sebanyak 54,05 \% sedangkan pada kelas kontrol sebanyak $40 \%$. Tidak terdapat perbedaan antara nilai N-gain pada kelas perlakuan dan kontrol. Penerapan model flipped learning tidak berpengaruh terhadap pemahaman mahasiswa tetapi sudah dapat meningkatkan pemahaman mahasiswa pada materi metode squash. Kesimpulan: Model flipped learning berpotensi diterapkan sebagai solusi bagi permasalahan praktikum yang terkendala keterbatasan waktu. 


\section{Introduction}

Various problems in biology learning require solutions for the learning objectives that could be achieving. This solution needs to involve the components of learning activities was including the interaction between teachers and students. Problems in learning activities could be characterisation into student behaviour and learning outcomes (Priyayi et al., 2018). In biology learning, abstract material problems, constraints of time, cost, and laboratory safety in practicum, one solution was implementing a virtual laboratory (Susilawati, 2019). However, the implementation of virtual laboratories had a weakness. The students did not have direct experience interacting with learning objects (touching, smelling), underdeveloped student skills in using laboratory equipment, and lack of solving problem experiences (Nirwana, 2016; Scheckler, 2003; Tatli \& Ayas, 2010). Another solution to solve the limiting time in practicum was by applying the flipped learning model (Ridha et al., 2016).

Flipped learning was a learning model that reverses student activities usually carried out in class to be at home while activities at home were done in the classroom (Bergmann \& Sams, 2012). The flipped learning paradigm utilised internet technology while maintaining classroom learning to improve collaborative skills and critical thinking (Ahmed, 2016). Implementing flipped learning in higher education was expected to overcome the problems and challenges faced by conventional learning models and lead to active learning strategies. Flipped learning uses class time more effectively to learn knowledge at a higher Bloom taxonomy level (analysis, evaluating, and creating) while remembering and understanding were carried out before face to face (Krathwohl, 2002).

Practicum was an integrated part and cannot be separated from microtechnique courses. Subject learning outcomes include not only cognitive abilities but also psychomotor abilities. The learning outcomes of microtechnique subjects include students having the skills to make fresh and preserved preparations, and applying various methods in making preserved preparations; students can describe the observations of these preparations. To meet the course's learning outcomes, a learning experience was needed in the form of practicum making fresh and preserved preparations and interpreting the results of the observations of these preparations. Limited face-to-face time was the main problem so that students do not get all the maximum learning experiences of microtechnique practicum. This has an impact on the ability of students to analyse and evaluate the results of their low practicum and understanding of the material that was not in-depth. The short practicum time also causes lecturers to be less than optimal in assisting, especially when students do activities that require higher thinking skills. This causes students not to get much feedback from lecturers to experience more difficulties when encountering more complex problems related to practicum.

Microtechnique was a scientific biology course that was integrated with the practicum presented for biology education students. In this course, students are equipped with the skills to make fresh and preserved preparations. These skills are needed for a prospective biology teacher to support the learning planned for students at school.

Based on this description, one solution that can solve problems in microtechnique learning was the implementation of the flipped learning model. The flipped learning model has the advantage of providing sufficient face-to-face time for students to conduct practicum and class discussions (Romero-García et al., 2015). This advantage gives the interaction between lecturers and students and between students to become more intensive and the learning environment in the classroom to be more dynamic and interactive. Lecturers act as facilitators who help students apply concepts (procedural knowledge) and are creatively involved with learning objects while students act as active learners and collaborators for other students (Barral et al., 2018). Class activities are more of implementation, analysis, evaluating, and creating while remembering and understanding activities have been carried out by students independently before attending a class (Estes et al., 2014). Before attending class, student activities are studying the material in instructional videos, journal articles, and practical instruction videos (Sinaga, 2017).

The advantage obtained from the implementation of the flipped learning model was the increased quality of learning (Malto et al., 2018). In this learning model, learning activities are centered on students, not on lecturers (Bergmann \& Sams, 2012). Flipped learning provides opportunities for students to study independently so that students' active role was one of the main factors determining the development of student knowledge and the achievement of course learning objectives (Cagande \& Jugar, 2018).

The implementation of the flipped learning model to improve the quality of learning was one form of adaptation to the context of the times. In this era of the industrial revolution 4.0, the development of learning quality should integrate Information and Communication Technology (ICT). The quality of learning that was getting better contributes to supporting course learning outcomes (Ismail \& Abdulla, 2019). Flipped learning utilises digital content, applications, various web tools, and distance learning platforms which are expected to create a more creative, innovative, and interesting learning atmosphere (RomeroGarcía et al., 2015); to increase student interest in learning and provide meaningful learning experiences for students (Kurniawan et al., 2016). The integration of ICT in flipped 
learning has the advantage that learning activities are not limited by time and space (Hamdan et al., 2013).

The flipped learning model has been used in higher education in various countries. The implementation of flipped learning in Indonesia that has been published includes solving the problems of self-regulated learning of students in basic chemistry courses (Sinaga, 2017); learning outcomes and learning independence in physics learning (Choiroh et al., 2018); attitudes and independent learning in mathematics learning (Damayanti \& Sutama, 2016); students' conceptual understanding in science learning (Putri et al., 2019); students' critical thinking skills on colloid material (Salma et als, 2016). Based on these descriptions, the flipped learning model can overcome problems faced in microtechnique courses and improve student understanding. The advantages of this learning model are also expected to improve the quality of the learning held.

In previous studies, the flipped learning model has never been applied to microtechnique subjects and was integrated with practicum. The understanding analysed in this study differed in cognitive levels between pre-test (remembering and understanding) and post-test (analysis, evaluating, and creating). This study aimed to examine the implementation of the flipped learning model and its effect on student understanding of the squash method material in microtechnique course.

\section{Methods}

\section{Research scope}

The research was conducted on the squash method material in the microtechnique course of the 2019/2020 academic year. The flipped learning model was applied to the treatment group and then analysed the students' understanding of the learning material. A sample of 72 students of a biology education study program at a private university in Indonesia took microtechnique courses.

\section{Research designs}

The research was a quasi-experimental study with a non-equivalent control group design. This design was almost the same as the pre-test-post-test control group design, but the control and treatment groups were not choosen randomly (Sugiyono, 2015).

Table 1. Research design

\begin{tabular}{cccc}
\hline Class & Pre-test & Treatment & Post-test \\
\hline A & $\mathrm{O}_{1}$ & $\mathrm{X}$ & $\mathrm{O}_{2}$ \\
B & $\mathrm{O}_{3}$ & $\mathrm{Y}$ & $\mathrm{O}_{4}$ \\
\hline
\end{tabular}

This study involved a treatment class with 37 students and a control class with 35 students. Treatment $X$ was the treatment class with the flipped learning model, and treatment $\mathrm{Y}$ was the control class with the conventional learning model (lecture method). The students' initial understanding of the material was measured through a pretest in the treatment class $\left(\mathrm{O}_{1}\right)$ and the control class $\left(\mathrm{O}_{3}\right)$. Students' final understanding after learning was measured by post-test in the treatment class $\left(\mathrm{O}_{2}\right)$ and the control class $\left(\mathrm{O}_{4}\right)$ (Table 1).

\section{Research procedures}

The implementation of flipped learning in learning was carried out by utilising the Learning Management System (LMS) facility (http://belajar.usd.ac.id/) (Figure 1.). This research procedure includes the preparation stage, the preparation of instruments, and the implementation of learning.

The preparation stages included the preparation of study materials and practical worksheets as well as student preparation. The learning materials were in the form of learning videos, journal articles, practicum instruction videos, and pictures of the observations of preparations (Figure 2.). The learning materials were uploaded to the LMS using the menu available in "add activity or resource" in the form of "file" and "label". "Forum" menu was also used to facilitate all students to be able to see the results of other groups' observations and discuss outside face-to-face time to prepare for the post-test.

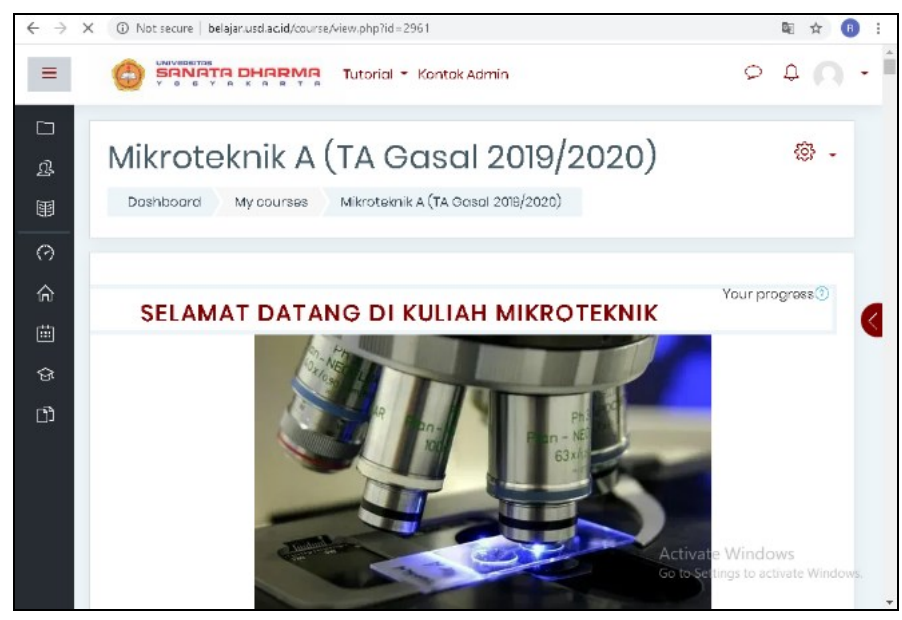

Figure 1. LMS page view

The depth of the material is arranged in the Semester Learning Plan for Micro-technical Subjects, such as the meaning and function/role of the squash method in research; good slide criteria in the squash method; materials and methods; application of the squash method in biological and other field research; and cell division. The squash method was a method for obtaining a slide by squeezing a piece of tissue or an organism as a whole so that a thin slide could be observed under a microscope (Suntoro, 1983). In this study, the squash method was used to make preparations for plant cell division. Preparation of students was carried out through socialisation of the learning stages with the flipped learning model carried out on the squash method material. 


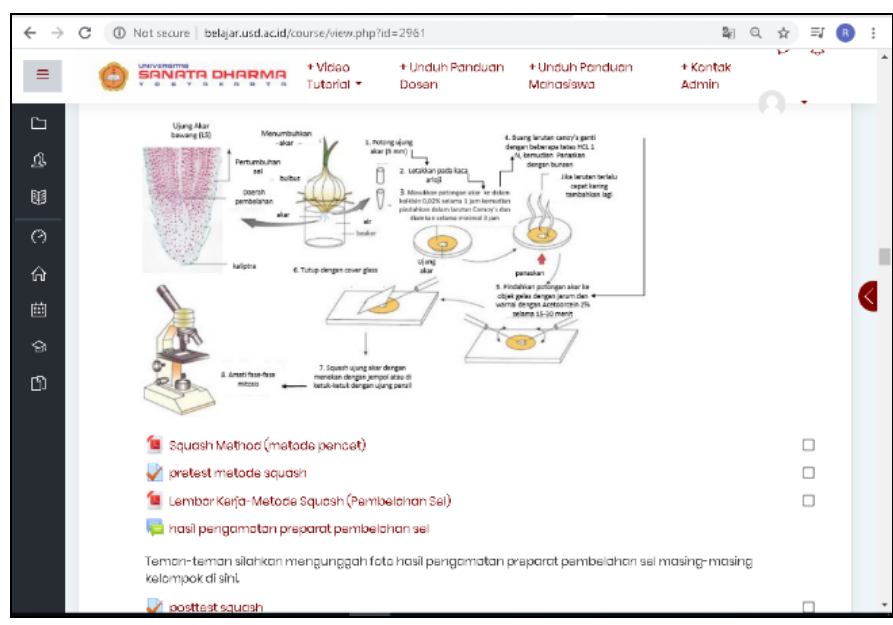

Figure 2. Display of learning materials in LMS

The next stage was the preparation of an evaluation instrument. The test included pre-test (10 items multiple choice of and five items matching statement) and post-test (5 items essay). Because the purpose of the test in this study was to measure the mastery of the learning material's content, the validation was related to content validity. Content validation was done by asking for the opinion (judgment) of a material expert. Content validation included conformity aspects with the material and Semester Learning Plan (depth and breadth); conformity with learning objectives; suitability with the cognitive level being evaluated; representing/reflecting the entire content of the material proportionally (Djaali \& Muljono, 2008).

Pre-test and post-test questions were uploaded to the LMS using the quiz menu which available in "add activity or resource". Pre-test and post-test were prepared at the LMS 1 week before face-to-face lectures (Figure 3.). Students could do the test according to the schedule provided in onetime processing opportunity and the time for taking the test was limited.

The next stage was the implementation of learning Learning was carried out following the stages designed and in accordance with the activity description in Table 2. and Table 3. After the learning ends, the next stage was data collection (evaluating student understanding) and data analysis.

\section{Learning Designs}

The learning process was carried out following the stages designed in Table 2. and following the description of the activities in Table 3. The learning process was divided into three stages. There were pre-class, class activity, and post-class. Practicum making preparations, observing the results, and discussing the practicum worksheet was carried out within 140 minutes in the treatment class, while in the control class, only 90 minutes (Table 3.).

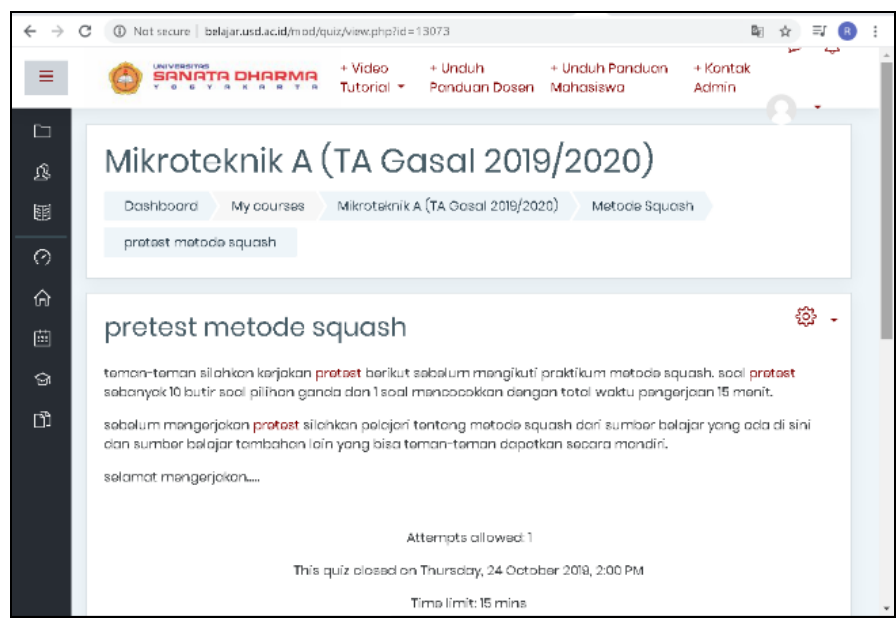

Figure 3. Display of the pre-test start page

Table 2. The stages and activities in the flipped learning model

\begin{tabular}{cl}
\hline Stages & \multicolumn{1}{c}{ Activities } \\
\hline Pre-class & To study materials (conceptual) \\
& Pre-test \\
Class & to work the practicum and discussion \\
activity & (procedural) included \\
& working on practicum worksheets \\
Post-class & Post-test \\
\hline
\end{tabular}

Table 3. Description of activities and time allocation

\begin{tabular}{lcc}
\hline \multicolumn{1}{c}{ Activities } & \multicolumn{2}{c}{ Time (minutes) } \\
\cline { 2 - 3 } & $\begin{array}{c}\text { Control } \\
\text { class }\end{array}$ & Treatment class \\
\hline $\begin{array}{l}\text { Delivery of materials } \\
\text { and practical } \\
\text { instructions }\end{array}$ & 20 & $\begin{array}{c}\text { Online } \\
\text { (pre-class) }\end{array}$ \\
$\begin{array}{l}\text { Pre-test } \\
\text { Practicum and } \\
\text { discussion }\end{array}$ & 15 & $\begin{array}{c}\text { Online } \\
\text { (pre-class) } \\
\text { Course plans } \\
\text { explanation for the } \\
\text { next class }\end{array}$ \\
$\begin{array}{l}\text { Post-test } \\
\text { Total }\end{array}$ & 10 & 140 \\
\hline
\end{tabular}

\section{Data Collection and Data Analysis}

The data collection technique used was a test. The type of test used in the pre-test was multiple choice while the post-test was an essay. The pre-test included questions to evaluate the ability to remembering and understanding while the post-test evaluated the ability to analyse, evaluate, and create. The tests evaluated different cognitive levels because class activities focus more on analysing, evaluating, and creating in the treatment class. In contrast, activities analysed, evaluated, and created are carried out independently by students in class control, outside the classroom (Figure 4.). According to (Brame, 2012), based 
on the application of Bloom's (revised) taxonomy on flipped learning, students do activities with lower cognitive levels (Lower Ordered Thinking Skills), (remembering and understanding) outside the classroom while activities with a higher cognitive level (Higher Ordered Thinking Skills) (analysis, evaluating and creating) in the class.

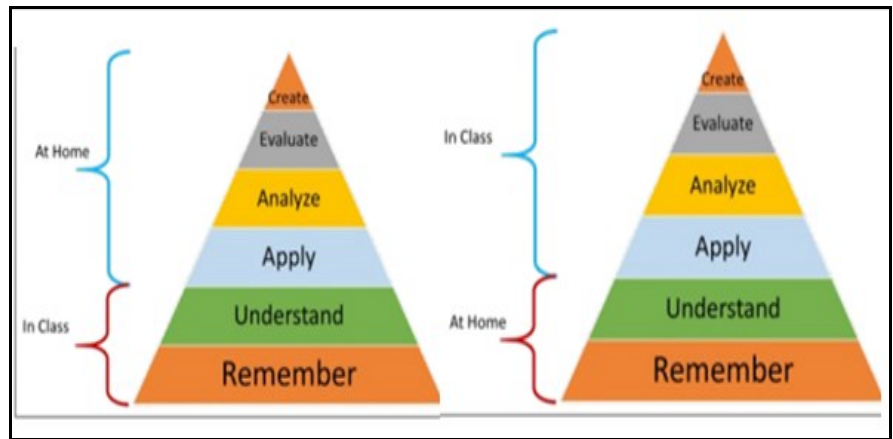

Figure 4. Distribution of cognitive levels in flipped learning (right) and conventional learning (left) (Bergman \& Sams, 2014; Andrade \& Coutinho, 2017).

The data on the two classes' pre-test scores were tested t-test to determine whether there was a difference between the two. Because there was a difference in the mean value of the pre-test in the two classes, then the pre-test and post-test value data in each class were used to calculate the $\mathrm{N}$-gain value. The $\mathrm{N}$-gain formula was as follows:

$\mathrm{N}$-gain $=$ post-test score -pre-test score

Ideal score - pre-test score

Note: the ideal score was the maximum (highest) value that could be obtained.

The N-gain value was categorised based on Table 2. Furthermore, the N-gain value of the treatment and control classes was analysed for normality and homogeneity then the Mann-Whitney $U$ test was carried out to determine whether there was a difference in the $\mathrm{N}$-gain value between the two.

Table 4. N-gain value classification category

\begin{tabular}{cc}
\hline Nilai N-gain & Kategori \\
\hline $\mathrm{g}>0,7$ & High \\
$0,3 \leq \mathrm{g} \leq 0,7$ & Medium \\
$\mathrm{g}<0,3$ & Low
\end{tabular}

\section{Results}

\section{Learning design using flipped learning model}

The flipped learning model applied referred to Estes et al. (2014) with activity modifications in flipped learning stages (Figure 5.). The learning process was divided into three stages. There were pre-class, class activity, and postclass. Pre-class was the stage of learning before face to face in class. Class activity (in-class) was the face-to-face learning stage in class. Post-class was the learning stage after face to face.

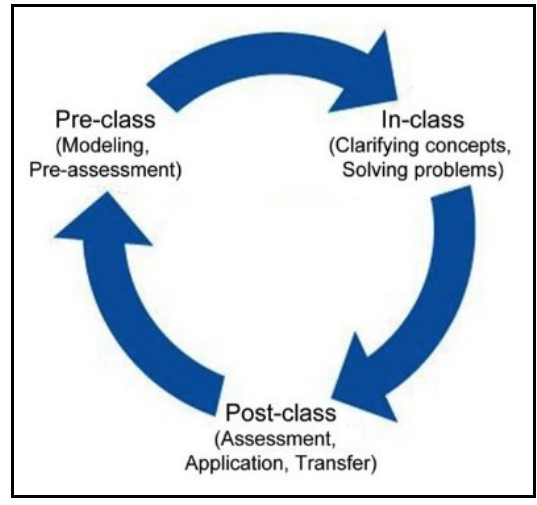

Figure 5. The stages of the flipped learning model (Estes et al., 2014).

In the pre-class, student activities focused on conceptual knowledge (Nouri, 2016). Students must learn materials that have been uploaded through the Moodle-based LMS. The learning materials were instructional videos, journal articles, practical instructions videos, and slide observation pictures. One form of lecturer assistance at the pre-class was holding a pre-test (Gariou-Papalexiou et al., 2017). For lecturers, pre-test played a role in monitoring student learning activities during pre-class. The lecturer could ensure that students learned the study materials that were already available in the LMS before face to face through the pre-test. In addition to the pre-test, an alternative that could be done was to assign students to make summary notes of the study material (Bergmann \& Sams, 2014). The pre-test was carried out independently by students at the LMS (online) and could be done from the 3rd day before face-to-face until the lectures began.

At the class activity, student activities focused on procedural knowledge (Nouri, 2016). This activity was more active and participatory (Gariou-Papalexiou et al., 2017). Students carried out practicum making preparations using the squash method and discuss in small groups (3-4 students per group). Small groups were selected so that each member got a part in group assignments, increased the opportunities for interaction between group members, improved critical thinking skills, exploratory skills in practicum, and reflected on experiences. Small groups had an advantage over large groups in developing attitudes and values (Edmunds \& Brown, 2010).

At the end of the practicum, each group was required to submit a practicum worksheet that contained the practical objectives, observations, and answers to the discussion guide questions provided on the worksheet. Questions that must be discussed in the practicum worksheet included interpreting the results of the observations, the obstacles faced in making preparations, and their solutions. 
Students combined information obtained in the preclass stage and experience interacting with learning objects in a practicum at the class activity. The pre-class information was regarding the materials, methods, and good slides criteria in the squash method, while the experience of interacting with learning objects in the practicum was in the form of observation of preparations. This information synthesis activity could develop higherorder thinking and critical thinking skills (Bergmann \& Sams, 2014; Dusenbury \& Olson, 2019).

In the post-class, students did the post-test independently through LMS (online). The post-test was done to measure understanding after the implementation of the flipped learning model. Post-test and pre-test were carried out through LMS considering time efficiency so that class activity could be maximum for practicum.

The time available was considered more adequate in the treatment class than the control class because a slide making process took 90 minutes using the squash method. In the control class, making and observing the results could not be completed in the time available, so students were assigned to continue observing the results independently after the class.

\section{Student understanding of learning material}

The students' understanding of the material was based on the score of pre-test and post-test. Table 4 shows that the lowest post-test score of students in the treatment class was 47.5 , while in the control class was 32.5. Figure 6 shows that the increase in the treatment class's mean value was higher than the control class $(5.2>0.82)$.

The students who showed the $\mathrm{N}$-gain score in the high and moderate categories in the treatment class were 54.05 $\%$ while those in the control class were lower (40\%). Students who showed a low category N-gain score in the treatment class were $45.95 \%$ while those in the control class were higher at $60 \%$ (Table 6.).

Table 5. The score of pre-test and post-test

\begin{tabular}{ccccc}
\hline \multirow{2}{*}{ Components } & \multicolumn{2}{c}{ Pre-test } & \multicolumn{2}{c}{ Post-test } \\
\cline { 2 - 5 } & $\mathrm{A}$ & $\mathrm{B}$ & $\mathrm{A}$ & $\mathrm{B}$ \\
\hline Number of & 37 & 35 & 37 & 35 \\
stundents & & & & \\
Lowest score & 41.7 & 31.7 & 47.5 & 32.5 \\
Highest score & 95 & 95 & 100 & 100 \\
Average & 77.16 & 75.39 & 82.36 & 76.21 \\
SD & 15.47 & 18.58 & 13.19 & 18.12 \\
\hline
\end{tabular}

*note: A (treatment class); B (control class)

The results of the t-test indicated a difference between the mean value of the control and treatment class pre-test $(\mathrm{t}<0.05)$. So, the initial ability of students in the two classes was different. The $\mathrm{N}$-gain value was calculated to analyse the effect of flipped learning on student understanding.

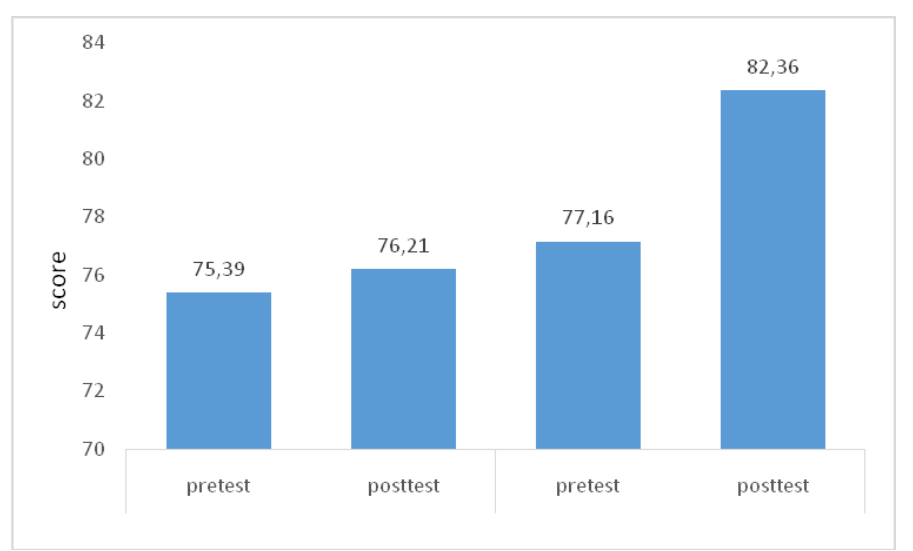

Figure 6. The average score of pre-test and post-test

Table 6. Analysis of the percentage of $\mathrm{N}$-gain in the treatment and control classes

\begin{tabular}{ccc}
\hline Classes & Category & $\begin{array}{c}\text { The percentage of } \\
\text { students (\%) }\end{array}$ \\
\hline \multirow{3}{*}{ Treatment } & High & 24,32 \\
& Medium & 29,73 \\
& Low & 45,95 \\
Control & High & 25,71 \\
& Medium & 14,29 \\
& Low & 60 \\
\hline
\end{tabular}

Based on the Shapiro-Wilk normality test, the treatment class's $\mathrm{N}$-gain value was not normally distributed with $\mathrm{p}<$ 0.05 , while the control class was also not normally distributed with $\mathrm{p}<0.05$ (Table 7.). Levene's homogeneity test, the $\mathrm{N}$-gain value of the treatment and control classes, was not homogeneous with $\mathrm{p}<0.05$ (Table 8.).

The Mann-Whitney $U$ test was carried out to see the difference in $\mathrm{N}$-gain values between treatment and control classes. It was obtained $\mathrm{p}>0.05$ so that there was no difference between the $\mathrm{N}$-gain values in the treatment and control classes.

Table 7. The result of the N-gain normality test

\begin{tabular}{|c|c|c|c|}
\hline & \multicolumn{3}{|c|}{ Shapiro-Wilk } \\
\hline & Statistic & $\mathrm{df}$ & Sig. \\
\hline N-gain & 0,804 & 37 & 0,000 \\
\hline $\begin{array}{l}\text { Control class } \\
\text { N-gain } \\
\text { Treatment class }\end{array}$ & 0,574 & 35 & 0,000 \\
\hline
\end{tabular}

Table 8. The result of N-gain homogeneity test

\begin{tabular}{cccc} 
Levene statistic & df1 & df2 & Sig. \\
\hline 9,386 & 1 & 70 & 0,003 \\
\hline
\end{tabular}

\section{Discussions}

In this study, the pre-test and post-test scores of the treatment class were higher than the control class (Table 5.). One of the factors that influenced the results was the learning environment's flexibility as a pillar of flipped learning (Hamdan et al., 2013). The treatment class students were given the freedom to choose where and when to do the pre-test and post-test. The students could 
do it if they felt ready according to the deadline set by the lecturer. In contrast, the control class students were required to do the pre-test and post-test in class according to the activity class schedule regardless of the readiness of students so that they could not get a high score (Rusdi et al., 2018).

Flexibility in flipped learning was one of the advantages of learning, and its impact could be felt directly by students. Nouri, (2016) reported that flipped learning's implementation received a positive response from $75 \%$ of students, especially in terms of video use, flexibility, and mobility in flipped learning. In this learning, students took the test using Socrative (a distance learning platform), which could be flexible and mobile accessed via a smartphone, tablet, or computer. Flipped learning was suitable to the context of students related to technological progress. Flipped learning could also answer the demands of learning in higher education to lead to a more flexible, effective, active, and student-centered learning strategy to overcome the limitations of conventional learning models.

One of the determinants of the success of flipped learning was the activeness and independence of student learning (Malto et al., 2018). Students had the freedom to be able to set their study schedule, where and when to study to prepare the pre-test and where and when to do the pre-test and post-test according to the time limit set by the lecturer. Risniani \& Husein (2019) also reported that learning that combines e-learning with activity class (blended learning and flipped learning) was considered to be able to support independent learning by $95 \%$ of students.

The higher pre-test score in the treatment class (Table 5.) was also caused by the implementation of the flipped learning model to provide opportunities for students to learn according to their needs (Bergmann \& Sams, 2012). To prepare the pre-test, students watched instructional videos, read journal articles and watched practical instructions videos according to their needs. For students who learn fast, reading 1-2 times were enough, but for students who are slow learners, reading could be done repeatedly until it was enough. When watching videos, students could slow down, speed up and stop the video and even repeat certain parts according to their needs (Hamdan et al., 2013). In the study of Barral et al. (2018), $54 \%$ of students watched videos 1-2 times; $31 \%$ of students watched 3-4 times; $10 \%$ watched > 5 times. Students were motivated to watch repeatedly until they understood the learning materials because there became material for the pre-test. In Nouri, (2016), students strongly agreed that stopping, repeating, and speeding up videos was very useful in learning. The video was a lecture recording with a duration of 60 minutes. If the video included the entire learning material, then students who could not understand the material in one look could repeat the videos to better understanding the material.

When the students listened to lecturers' explanations in class, the students who were slow to learn could ask for reexplanations, but some students felt embarrassed, which could be quite disruptive to learning and time consuming (Gariou-Papalexiou et al., 2017). These weaknesses could be overcome by using video on flipped learning. Students who learned fast could also accelerate and pass material that was already understood. The flipped learning model was better to understand the differences in student characteristics in terms of learning speed so that learning was more personal (Blau \& Shamir-Inbal, 2017). This model also provided an opportunity for all students to get the best results. One of the flipped learning advantages was diverting learning from large groups to individual study rooms with the help of technology so that the learning activity was more personal (Hamdan et al., 2013; Taylor, 2015).

Instructional videos, journal articles and practicum instructional videos contributed to students' pre-test scores. If the students did not study the learning material, they would have difficulty doing the pre-test and the practicum. It was because the learning materials included tools, materials and practical work methods. The lecturer deliberately prepared the learning material so that students prepared themselves before meeting face to face. Awareness of the importance of studying learning materials before face to face in class could foster student learning independence (Malto et al., 2018). Based on Ihm et al. (2017) research, the implementation of flipped learning caused most students to feel more independent and more prepared before facing the class activity. This study showed a positive correlation between pre-test and students' readiness to learn so that the test could be used to evaluate student readiness. Flipped learning could foster and increase student learning independence, but according to Sirakaya \& Özdemir (2018), this increase was not significant for groups of students who already have independent learning characters. In the group of students with high learning independence, the analysis of the pretest scores also showed students' high learning readiness.

The learning materials contributed to the students' pretest scores. However, the effect of learning material has not been studied yet in this study. The preference of learning materials by the students has not been analysing. There were $91.89 \%$ of students stated that they preferred video because the visualisation was easier to understand, more interesting, so it was not easy to cause drowsiness. The use of digital content in learning, such as videos, national journal articles, and pictures, could create the learning atmosphere more interested and increase interest in learning to increase student understanding. Based on Risniani \& Husein (2019), digital content in flipped learning 
and blended learning was also considered attractive by $95.24 \%$ of students. The learning was also considered fun by $80.95 \%$ of students, making it easier to access all students' learning materials (100\%).

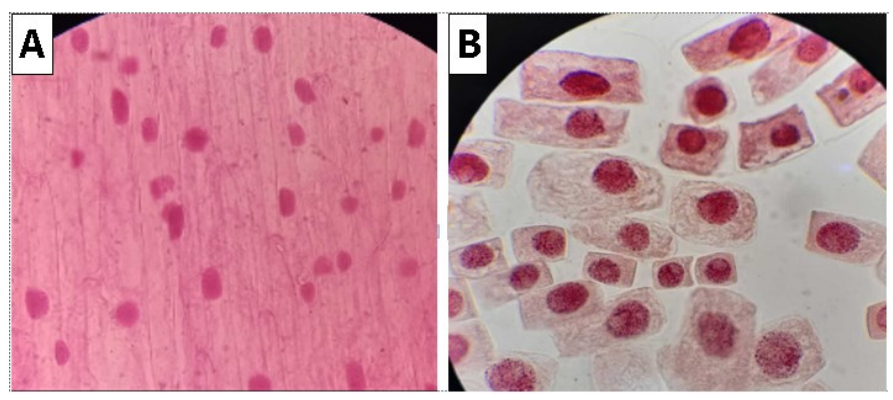

Figure 7. The observations of the squash method showed: A. cells appeared to accumulate and B. cells appeared to spread out from one another

The increase in the mean value in the treatment class was higher than the control class $(5.2>0.82)$ (Figure 6.). The same thing was also found in the research of Rusdi et al. (2018) that the mean score of students' cognitive learning outcomes in the experimental class with the flipped classroom learning model was higher than the control class with the STAD model.

In this study, the treatment class had a mean score higher than the control class because the treatment class implement flipped learning (Figure 6.). Flipped learning improved student interaction with lecturers through mentoring in class (Bergmann \& Sams, 2012). The experience of being accompanied when observing slides did not occur in the control class because the observations were conducting after class. In the control class, the time available was only enough to make slides. In this case, interpretation and observation results, which the lecturer accompanied, provided the opportunity for students to consult directly. For example, to conclude that the slides were classification as a good one or not.

Figure 7 was an observation result photo of slides made by students. Students needed to be depth to conclude that Figure 7.A. showed a poor slide while Figure 7. B. showed a slide that had not met expectations. Figure 7.A. showed that the resulting slide was not good because the cells were stacked on top of each other, while B showed the cells that were scattered about each other but did not find the expected cell division phases. The interpretation of the results of these observations was an example of activities at the cognitive level of C5 (evaluating), which was to assess the quality of preparations based on a good slide criterion. The criterion of a good slide referred to in the squash method of cell division was to show cells that were mutually dispersed cells; was not accumulate and form a single layer of cells, and the phases of cell division and chromosomes appeared coloured.

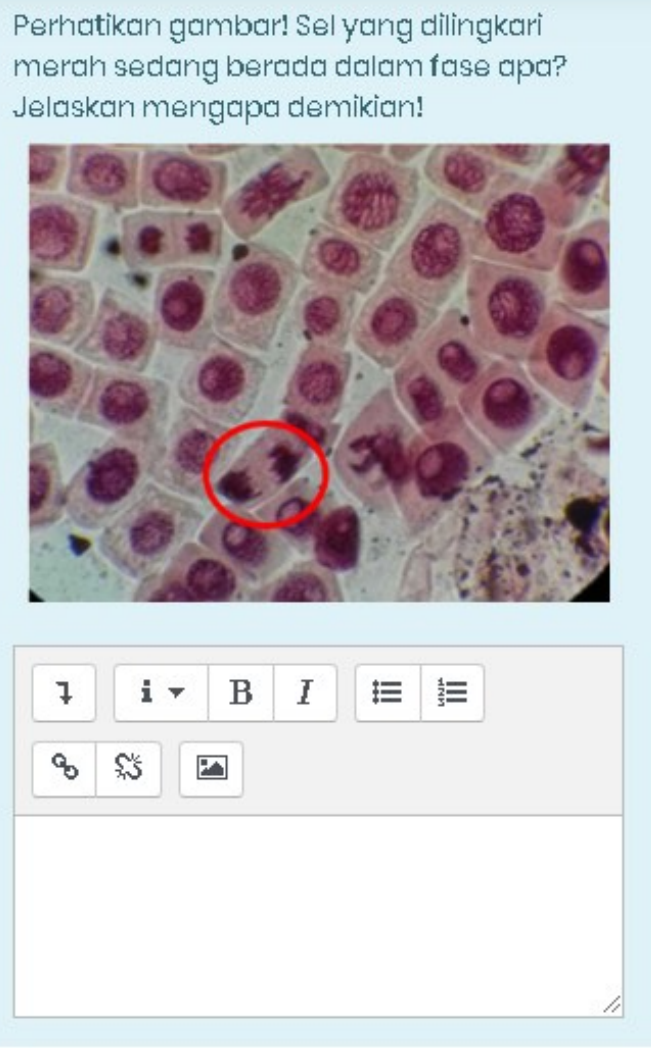

Figure 8. One of the question in post-test

Observation interpretation of the result impacted higher post-test scores in the treatment class than in the control class. It was because the questions presented in the posttest were analysed and evaluated in nature. The post-test was not only about the preparation but also the analysis and evaluation of the observation results. One of post-test question could be seen in Figure 8. In this question, students were asked to identify which cell was in which division phase and explain why.

Analysis and evaluation questions could be done well by students, due to their experience of interpreting observations during assisted lab work, which was not constrained by time constraints. Rusdi et al. (2018) stated that the percentage of achievement of learning outcomes in the treatment class (flipped class) was higher than the control class, both from cognitive levels C1 to C6. Barral et al. (2018) stated that the results of evaluating cognitive abilities at a lower level showed an increase in the ability to remember basic concepts and understanding. It was due to the experience of students in applying the concepts they have learned in pre-class.

Flipped learning maximised class activity to explore learning objectives through student interaction with lecturers and interaction between students (Ahmed, 2016). Student interaction with lecturers was related to learning material and direct, inspire and encourage students (Bergmann \& Sams, 2012). For example, in this study, when students got poor results for squash slide because the cells still appear to accumulate, the lecturer could encourage 
students to repeat the mounting stage of the preparations. When students did not get any of the cell division phases, they could direct students to evaluate how the work had been done. In Cagande \& Jugar (2018) research, teachers who apply flipped learning stated that they know their students better and understand better students' difficulties in learning.

In the treatment class, student interaction could be maximised with the time available. Mccollum et al. (2017) reported that flipped learning was suitable for students who still did not know their peers at the initial level. In this study, a student stated that it was easier to get to know his friends when learning in class, even in large classes. In the research of Kanelopoulos et al. (2017), students who prepare well in pre-class help their friends who are not. These students supported discussion activities so that students who did not prepare themselves were more confident in asking questions and conveying ideas. According to Gomez-Lanier (2018), students stated that they could listen better and support each other in conveying ideas during the discussion. Interaction between students was not only about relationships but also related to learning material. In this study, students discussed the results of observations made in groups while with other group friends, students could compare, evaluate, and provide suggestions on the results of other groups' observations. In other learning models, such interactions also occurred but in flipped learning, these interactions could be facilitated directly face-to-face in class with sufficient time (Table 3.) and a supportive learning environment. This interaction experience between students was very necessary to improve the skills of collaboration and solving more complex problems (Gomez-Lanier, 2018; Ismail \& Abdulla, 2019).

Flipped learning allowed sufficient time to avoid rushing group discussions. Students also continued the discussion of results in the LMS forum. In learning that combines e-learning with activity class (blended learning and flipped learning), Risniani \& Husein (2019) reported that learning was considered to facilitate student discussion with other students by $52.38 \%$ of students and facilitates discussions with lecturers by $57.14 \%$ of students. The things that students liked the most in learning were presentations and discussions (42.86\%), the use of media (28.57\%).

The result showed that the high and medium $\mathrm{N}$-gain scores were the treatment class student (54.05\%) while a lower N-gain was the control class student (40\%) (Table 6.). The high n-gain scores in the treatment class were supported by the active role and participation of students during learning, both at the pre-class, class activity, and post-class stages, which determines the development of their knowledge (Cagande \& Jugar, 2018). In the research of Risniani \& Husein (2019), the mean score of students with blended learning showed a good category, proportional to the level of student participation in the good to an outstanding category, which is $95.24 \%$. Blended learning combined facial learning with e-learning and flipped learning which was used in this study was one of the models of blended learning.

In the flipped learning in the treatment class, students did the pre-test before face to face and got feedback in the form of the pre-test scores immediately after working. This could help students to measure their ability to understand the material. Students could find out the weaknesses and difficulties in the material at hand. As in Zainuddin et al. (2019), in this study, the lecturer clarified and confirmed the material face-to-face (Table 3.). The lecturer used this opportunity to help students with questions and answers related to the material in study materials, pre-test, and practicum. The question and answer could overcome misconceptions and increase student understanding so that it impacted increasing post-test scores (Figure 5.). After working on the pre-test, the feedback obtained by students could also increase students' motivation to better prepare themselves by studying harder to prepare for the post-test at the end of learning (Risniani \& Husein, 2019).

Statistical analysis showed no difference between the $\mathrm{N}$ gain value in the treatment and control classes, so the flipped learning model's implementation did not affect student understanding. Various factors could cause this. Dusenbury \& Olson (2019) reported that students needed to adapt to the flipped learning model. Students have not realised the importance of learning so that learning motivation and involvement in learning are low. Chellapan et al. (2000) reported that some of the students' negative perceptions were laziness, lack of self-confidence, and the hope of receiving knowledge (lecturer-centred learning). Another factor that determined the success of the implementation of blended learning and flipped learning was the instructional design related to the use of e-learning features in LMS and face-to-face lectures (Risniani \& Husein, 2019).

In this study, the flipped learning model's implementation was able to improve students' understanding, but the effect shown was not significant. The implementation of this model could be further developed in other materials constrained by the limited face-to-face time, such as in this study. The implementation of flipped learning also needed to be designed to fit the target and be preceded by the socialisation of instructional design to students to adapt students to the learning model to be used (Egbert et al., 2015). This flipped learning model also had the potential to be applied as a solution to other problems in learning while at the same time utilising the supporting facilities provided by the university, including wifi internet access and moodle-based LMS. 


\section{Conclusion}

The flipped learning model's application to the squash method material in microtechnique courses has been able to improve student understanding, but the effect shown is not significant. Further research was still needed to study student perceptions about the application of flipped learning in learning.

\section{Acknowledgement}

The authors would like to thank the Center for Learning Development and Innovation (PPIP) Universitas Sanata Dharma for funding this research.

\section{Declaration statement}

The authors declare that they have no known competing financial interests or personal relationships that could have influenced the work reported in this paper.

\section{References}

Ahmed, H. O. K. (2016). Flipped Learning As A New Educational Paradigm: An Analytical Critical Study. European Scientific Journal, ESJ, 12(10), 417-444. https://doi.org/10.19044/esj.2016.v12n10p417

Andrade, M., \& Coutinho, C. (2017). Implementing flipped classroom in blended learning environments: A proposal based on the cognitive flexibility theory. Journal of Interactive Learning Research, 28(2), 109126.

Barral, A. M., Ardi-Pastores, V. C., \& Simmons, R. E. (2018). Student learning in an accelerated introductory biology course is significantly enhanced by a flipped-learning environment. CBE-Life Sciences Education, 17(ar38), 19. https://doi.org/10.1187/cbe.17-07-0129

Bergmann, J., \& Sams, A. (2012). Flipped Your Classroom: Reach Every Student in Every Class Every Day. In International Society for Technology in Education (1st ed.). ISTE and ASDC. https://doi.org/10.5593/sgemsocial2016/B13/S03.043

Bergmann, J., \& Sams, A. (2014). The Flipped Classroom. CSE, 17(3), 4-27.

Blau, I., \& Shamir-Inbal, T. (2017). Re-designed flipped learning model in an academic course: The role of cocreation and co-regulation. In Computers and Education (Vol. 115, Issue April 2018). Elsevier Ltd. https://doi.org/10.1016/j.compedu.2017.07.014

Brame, C. J. (2012). Flipping the Classroom Inverted Classroom

Cagande, J. L. L., \& Jugar, R. R. (2018). The flipped classroom and college physics students' motivation and understanding of kinematics graphs. Issues in Educatioinal Research, 28(2), 288-307. https://doi.org/http://www.iier.org.au/iier28/cagande .pdf

Chellapan, L., Meer, J. Van Der, Pratt, K., \& Wass, R. (2000). To Flip or Not to Flip, That 's the Question : Findings
From an Exploratory Study Into Factors That May Influence Tertiary Teachers to Consider a Flipped Classroom Model. Journal of Open, Flexible and Distance Learning, 22(1), 6-21.

Choiroh, A. N. L., Ayu, H. D., \& Pratiwi, H. Y. (2018). Pengaruh Model Pembelajaran Flipped Classroom menggunakan Metode Mind Mapping terhadap Prestasi dan Kemandirian Belajar Fisika. Jurnal Pendidikan Fisika, 7(1), 1-5.

Damayanti, H. N., \& Sutama, S. (2016). Efektivitas Flipped Classroom Terhadap Sikap Dan Ketrampilan Belajar Matematika Di Smk. Manajemen Pendidikan, 11(1), 2-7. https://doi.org/10.23917/jmp.v11i1.1799

Djaali, \& Muljono, P. (2008). Pengukuran dalam Bidang Pendidikan (Y. B. Sudarmanto (ed.)). Grasindo.

Dusenbury, M. J., \& Olson, M. R. (2019). The Impact of Flipped Learning on Student Academic Performance and Perceptions. Collegiate Aviation Review International, 37(1), 19-44. https://doi.org/10.22488/okstate.19.100202

Edmunds, S., \& Brown, G. (2010). Effective Small Group Learning. In Amee Guides in Medical Education (Vol. 32, Issue 9). https://doi.org/10.1037/h0093814

Egbert, J., Herman, D., \& Lee, H. (2015). Flipped Instruction in English Language Teacher Education: A Design-Based Study in a Complex, Open--Ended Learning Environment. The Electronic Journal for English as a Second Language, 19(2), 1-23.

Estes, M., Ingram, R., \& Liu, J. C. (2014). A review of flipped classroom research, practice, and technologies. International HETL Review, 4(7).

Gariou-Papalexiou, A., Papadakis, S., Manousou, E. (Gelly), \& Georgiadu, I. (2017). Implementing a flipped classroom: A case study of biology teaching in a greek high school. Turkish Online Journal of Distance Education, 18(3), 4765. https://doi.org/10.17718/tojde.328932

Gomez-Lanier, L. (2018). Building Collaboration in the Flipped Classroom: A Case Study. International Journal for the Scholarship of Teaching and Learning, 12(2), 1-9. https://doi.org/10.20429/ijsotl.2018.120207

Hamdan, N., McKnight, P., McKnight, K., \& Arfstrom, K. M. (2013). A Review of Flipped Learning. Flipped Learning Network.

Ihm, J., Choi, H., \& Roh, S. (2017). Flipped-learning course design and evaluation through student self-assessment in a predental science class. Korean Journal of Medical Education, 29(2), 93-100. https://doi.org/10.3946/kjme.2017.56

Ismail, S. S., \& Abdulla, S. A. (2019). Virtual Flipped Classroom: New Teaching Model to Grant the Learners Knowledge and Motivation. Journal of Technology and Science Education, 9(2), 168-183. https://doi.org/https://doi.org/10.3926/jotse.478

Kanelopoulos, J., Papanikolaou, K. A., \& Zalimidis, P. (2017). Flipping The Classroom to Increase Students' 
Engagement and Interaction in a Mechanical Engineering Course on Machine Design. International Journal of Engineering Pedagogy (IJEP), 7(4), 19. https://doi.org/10.3991/ijep.v7i4.7427

Krathwohl, D. R. (2002). A Revision of Bloom's Taxonomy: Theory Into Practice, 41(4), 212-219.

Kurniawan, F. H., Setyosari, P., \& Ulfa, S. (2016). Flipped Classroom sebagai Sarana dalam Meningkatkan Kualitas Pembelajaran dan Keaktifan Siswa dalam Proses KBM. Prosiding Inovasi Pendidikan Di Era Big Data Dan Aspek Psikologinya, 139-144.

Malto, G. A. O., Dalida, C. S., \& Lagunzad, C. G. B. (2018). Flipped Classroom Approach in Teaching Biology: Assessing Students' Academic Achievement and Attitude Towards Biology. 4th International Research Conference on Higher Education, 540-554. https://doi.org/10.18502/kss.v3i6.2403

Mccollum, B. M., Fleming, C. L., Plotnikoff, K. M., \& Skagen, D. N. (2017). Relationships in the Flipped Classroom. The Canadian Journal for the Scholarship of Teaching and Learning, 8(3).

Nirwana, R. R. (2016). Pemanfaatan Laboratorium Virtual Dan E-Reference Dalam Proses Pembelajaran Dan Penelitian Ilmu Kimia. Phenomenon : Jurnal Pendidikan $M I P A$, $1(1)$ 115-123. https://doi.org/10.21580/phen.2011.1.1.451

Nouri, J. (2016). The flipped classroom : for active, effective and increased learning - especially for low achievers. International Journal of Educational Technology in Higher Education, 13-33. https://doi.org/10.1186/s41239-016-0032-z

Priyayi, D. F., Keliat, N. R., \& Hastuti, S. P. (2018). Masalah dalam Pembelajaran menurut Perspektif Guru Biologi Sekolah Menengah Atas (SMA) di Salatiga dan Kabupaten Semarang. Didaktika Biologi: Jurnal Penelitian Pendidikan Biologi, 2(2), 85-92.

Putri, M. D., Rusdiana, D., \& Rochintaniawati, D. (2019). Students' conceptual understanding in modified flipped classroom approach: An experimental study in junior high school science learning understanding in modified flipped classroom approach : An experimental study in junior high sc. IOP Conf. Series: Journal of Physics: Conf. Series, 1157 (2019, 1-7. https://doi.org/10.1088/1742$6596 / 1157 / 2 / 022046$

Ridha, M., Setyosari, P., \& Kuswandi, D. (2016). Pengaruh Flipped Mastery Classroom terhadap Perolehan Hasil Belajar Kognitif Mahasiswa. Jurnal Pendidikan: Teori, Penelitian, Dan Pengembangan, 1(4), 655-661. https://doi.org/10.17977/jp.v1i4.6211

Risniani, L. Y., \& Husein, A. (2019). Blended Learning: Pengembangan dan Implementasinya pada Mata Kuliah Fisiologi Tumbuhan. Bioeduscience, 03(02), 73-83.

Romero-García, C., Buzón-García, O., \& Touron, J. (2015). The Flipped Learning Model in Online Education for Secondary Teachers. Journal of Technology and Science
Education

$9(2)$,

$109-121$

https://doi.org/https://doi.org/10.3926/jotse.435

Rusdi, Evriyani, D., \& Praharsih, D. K. (2018). Pengaruh Model Pembelajaran Peer Instruction Flip dan Flipped Classroom terhadap Hasil Belajar Kognitif Siswa pada Materi Sistem Ekskresi. BIOSFER: Jurnal Pendidikan Biologi (BIOSFERJPB), 9(1), 15-19. https://doi.org/10.21009/biosferjpb.9-1.3

Salma, A. Z., Subarkah, C. Z., \& Aisyah, R. (2016) Peningkatan Keterampilan Berpikir Kritis Mahasiswa pada Materi Koloid Melalui Model Pembelajaran Flipped Classroom. Prosiding Snips 2016, 64-69.

Scheckler, R. K. (2003). Virtual labs: A substitute for traditional labs? International Journal of Developmental Biology, 47(2-3), 231-236. https://doi.org/10.1387/ijdb.12705675

Sinaga, K. (2017). Penerapan Flipped Classroom Pada Mata Kuliah Kimia Dasar Untuk Meningkatkan Self-Regulated Learning Belajar Mahasiswa. Jurnal Inovasi Pendidikan Kimia, 11(2), 1932-1944. https://journal.unnes.ac.id/nju/index.php/JIPK/article /view/10609

Sirakaya, D. A., \& Özdemir, S. (2018). The Effect of a Flipped Classroom Model on Academic Achievement, SelfDirected Learning Readiness , Motivation And Retention. Malaysian Online Journal of Educational Technology, 6(1), 76-91.

Sugiyono. (2015). Metode Penelitian Kuantitatif, kualitatif, dan $R \& D$. Penerbit Alfabeta.

Suntoro, H. (1983). Metode Pewarnaan (Histologi dan Histokimia). Bhratara Karya Aksara.

Susilawati, P. R. (2019). Implementation of Web-Based Virtual Laboratory Media in Learning. Jurnal Taman Vokasi, $\quad 7(2)$,

$122-128$ https://doi.org/10.30738/jtv.v7i2.6396

Tatli, Z., \& Ayas, A. (2010). Virtual laboratory applications in chemistry education. Procedia - Social and Behavioral Sciences, 9, 938-942. https://doi.org/10.1016/j.sbspro.2010.12.263

Taylor, A. (2015). Flipping Great or Flipping Useless? A review of the flipped classroom experiment at Coventry University London Campus. Journal of Pedagogic Development, 5(3), 57-65.

Zainuddin, Z., Habiburrahim, Muluk, S., \& Keumala, C. M. (2019). How do students become self-directed learners in the EFL flipped-class pedagogy? A study in higher education. Indonesian Journal of Applied Linguistics, $8(3)$,

678-690. 